\title{
Normas de Publicação na Revista de Direitos e Garantias Fundamentais
}

A "Revista de Direitos e Garantias Fundamentais", do Programa de Pós-Graduação em Direito da Faculdade de Direito de Vitória, com publicação semestral, iniciada em 2006, tem distribuição nacional. Aceita trabalhos que tenham conteúdo acadêmico e que versem sobre Direitos Fundamentais e/ou temáticas correlatas. No ato da submissão os autores deverão optar por uma das seções a seguir relacionadas. A última seção, por seu caráter mais abrangente, poderá recepcionar trabalhos que não se enquadraram nas seções anteriores.
a) Filosofia dos Direitos Fundamentais.
b) Hermenêutica, Jurisdição Constitucional e Cidadania.
c) Direito, Sociedade e Cultura.
d) Grupos Invisibilizados, Memórias e Lutas pelos Direitos Humanos.
e) Direitos Fundamentais Sociais.
f) Violência, Sistemas Penais e Democracia.
g) Estado, Democracia Constitucional e Direitos Fundamentais.

\section{Normas editoriais}

O Conselho Editorial da Revista é permanente, entretanto é facultada a ampliação desse Conselho em edições especiais que demandem discussão de temas específicos.

Os trabalhos são de estrita responsabilidade dos autores. As opiniões neles emitidas não exprimem, necessariamente, o ponto de vista da Faculdade de Direito de Vitória (FDV).

\section{Critérios de avaliação}

A publicação dos trabalhos dependerá dos pareceres de dois membros do Conselho Editorial, ou do corpo de pareceristas, que 
decidirão sobre a pertinência ou não da publicação dos originais, emitindo parecer consubstanciado. Em caso de divergência entre os dois pareceres, o artigo será submetido a um terceiro avaliador.

As alterações que se fizerem necessárias serão encaminhadas ao(s) autor(es) que se encarregará(ão) da reformulação apontada.

Em caso de aprovação, o trabalho deverá ser submetido à revisão ortográfica e gramatical, devendo o autor se responsabilizar pelas correções que precisarem ser feitas.

Os textos serão avaliados a partir dos seguintes critérios:

a) Introdução - será observada a apresentação necessária do item "estrutura do artigo"

c) Desenvolvimento - será verificada a pertinência do conteúdo abordado ao objetivo delineado.

d) Conclusão - será avaliada a retomada dos objetivos e na forma de síntese de uma provável resposta e/ou encaminhamento/ sugestão.

e) Título - expressar com clareza o objeto de estudo abordado no artigo.

f) Problematização, debate e fidelidade ao tema.

g) Objetividade e clareza de exposição.

h) Argumentação científica consistente.

i) Pertinência dos autores citados e discussão.

j) Relevância do tema.

\section{Apresentação dos trabalhos}

Os textos não poderão conter qualquer informação de autoria ou qualificação dos autores. Tais informações deverão ser preenchidas no formulário próprio de cadastro do sistema da revista.

Os artigos deverão atender aos seguintes conteúdos e nesta ordem: 
- Título em português.

- Título traduzido para o inglês.

- Sumário.

- Resumo em português (máximo 100 palavras).

- Resumo traduzido para o inglês.

- Três palavras-chave em português.

- Três palavras-chave traduzidas para o inglês.

- Introdução.

- Desenvolvimento.

- Conclusão/Considerações finais.

- Notas de fim (todas as notas de rodapé explicativas).

- Referências.

Observação: os artigos em língua estrangeira deverão apresentar tradução do título, resumo e palavras-chave em português.

As citações deverão ser indicadas no texto pelo sistema de chamada AUTOR-DATA, de acordo com a Norma da ABNT NBR 10520-2002.

Caso o trabalho seja resultado de pesquisa financiada, esta deverá ser mencionada na primeira nota de fim.

Os trabalhos oriundos de projetos de pesquisa que envolvam, direta ou indiretamente seres humanos, deverão apresentar número de aprovação emitido por Comitê de Ética em Pesquisa, devidamente reconhecido pela Comissão Nacional de Ética em Pesquisa (CONEP) do Conselho Nacional de Saúde (CNS). 0 comprovante de aprovação do Comitê de Ética deverá ser anexado em PDF como documento suplementar no formulário de submissões.

A relação das referências aparecerá após as notas de fim, ao final do artigo, devendo ser citadas em ordem alfabética e obedecer às normas da ABNT.

Os artigos deverão ser inéditos, podendo ser escritos em português, espanhol, italiano, francês ou inglês. 
